\title{
Analisis Teknis dan Ekonomis Konversi Landing Craft Tank (LCT) Menjadi Kapal Motor Penyeberangan (KMP) Tipe Ro-ro untuk Rute Ketapang - Gilimanuk
}

\author{
Febriani Rohmadhana dan Hesty Anita Kurniawati \\ Jurusan Teknik Perkapalan, Fakultas Teknologi Kelautan, Institut Teknologi Sepuluh Nopember (ITS) \\ Jl. Arief Rahman Hakim, Surabaya 60111 Indonesia \\ e-mail: tita@na.its.ac.id
}

\begin{abstract}
Abstrak- Landing Craft Tank (LCT) tidak diperbolehkan beroperasi sebagai angkutan penyeberangan sesuai Surat Keputusan Dirjen Perhubungan Darat No. SK 885/AP.005/DRJD/2015 yang dikeluarkan pada tanggal 15 Maret 2015. Tugas Akhir ini bermaksud untuk melakukan analisis secara teknis dan ekonomis mengenai konversi kapal LCT Putri Sritanjung yang awalnya aktif beroperasi sebagai angkutan penyeberangan di Pelabuhan Ketapang menjadi Kapal Motor Penyeberangan (KMP) tiper Ro-ro. Pada analisis teknis dilakukan modifikasi kapal sesuai Peraturan Menteri Perhubungan No.39 dan No.80 tentang standar minimum angkutan penyeberangan, pemenuhan kriteria kekuatan konstruksi kapal, freeboard, tonase, dan stabilitas kapal. Modifikasi yang dilakukan terdiri dari penambahan ruang akomodasi penumpang dan stern ramp door. Setelah dikonversi kapal mengangkut 96 penumpang, 12 truk, dan 8 mobil. Tegangan konstruksi kapal maksimal sebesar 1.248,957 kg/cm2 lebih kecil dari tegangan ijin BKI. Tinggi freeboard minimum adalah 0,557 meter dengan sarat maksimum 2.193 meter, besarnya tonase kapal adalah 551 GT, dan kondisi stabilitas kapal memenuhi kriteria Intact Stability (IS) Code Reg. III/3.1.2. Sedangkan pada analisis ekonomis dilakukan perhitungan besarnya biaya konversi kapal. Besarnya biaya konversi LCT menjadi KMP tipe Ro-ro adalah sebesar 2.000.640.524 rupiah.
\end{abstract}

Kata Kunci- konversi kapal, LCT, KMP, surat keputusan, Ketapang - Gilimanuk

\section{PENDAHULUAN}

$L$ ANDING Craft Tank (LCT) merupakan jenis kapal yang

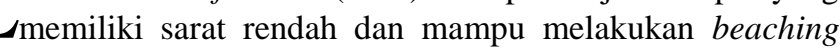
atau mendarat di pantai, tanpa menggunakan dermaga. Awalnya kapal jenis ini didesain sebagai kapal pengangkut alat tempur pada masa perang dunia II. Tetapi, seiring berjalannya waktu kini LCT banyak digunakan sebagai kapal pengangkut barang dan alat berat, seperti bulldozer, excavator, dan sebagainya. Bahkan di Indonesia LCT beralih fungsi menjadi angkutan penyeberangan, seperti di Pelabuhan Merak Bakahuni dan Pelabuhan Ketapang - Gilimanuk.

Tetapi, pada tanggal 15 Maret 2015 Dirjen Perhubungan Darat mengeluarkan Surat Keputusan Republik Indonesia No. SK 885/AP.005/DRJD/2015 tentang larangan penggunaan LCT sebagai angkutan penyeberangan. Keputusan ini tentu saja membuat pihak Gapasdap (Gabungan Pengusaha Nasional Angkutan Sungai, Danau, dan Penyeberangan) merasa keberatan. Surat keputusan ini dikeluarkan lebih cepat dari rencana awal yang baru akan dikeluarkan pada awal tahun 2017. Dikarenakan pihak Gapasdap belum bisa menyediakan kapal pengganti yang memenuhi standar dan spesifikasi angkutan penyeberangan dalam waktu yang sangat singkat.

Untuk memenuhi ketersediaan kapal penyeberangan di Pelabuhan Ketapang, dari kapal LCT yang sudah ada bisa konversi menjadi Kapal Motor Penyeber (KMP) tipe Ro-ro (Roll on / off). Dalam melakukan konversi kapal perlu dilakuakan analisis secara teknis dan ekonomis mulai dari awal pengerjaan sampai dihasilkan sebuah kapal dengan jenis berbeda. Kapal yang akan dijadikan studi kasus adalah LCT Putri Sri Tanjung milik Pemerintah Kabupaten Banyuwangi, salah satu kapal LCT yang awalnya aktif beroperasi sebagai angkutan penyeberangan di Pelabuhan Ketapang.

\section{TINJAUAN PUSTAKA}

\section{A. Rute Penyeberangan}

Rute penyeberangan Ketapang-Gilimanuk merupakan jalur penyeberangan antara Pulau Jawa dan Pulau Bali melalui selat Bali. Penyeberangan antar pulau ini berjarak kurang lebih 5.1 $\mathrm{km}$ dan bisa ditempuh dengan waktu rata-rata selama 30 menit dengan menggunakan kapal penyeberangan dengan kecepatan 5 knot.

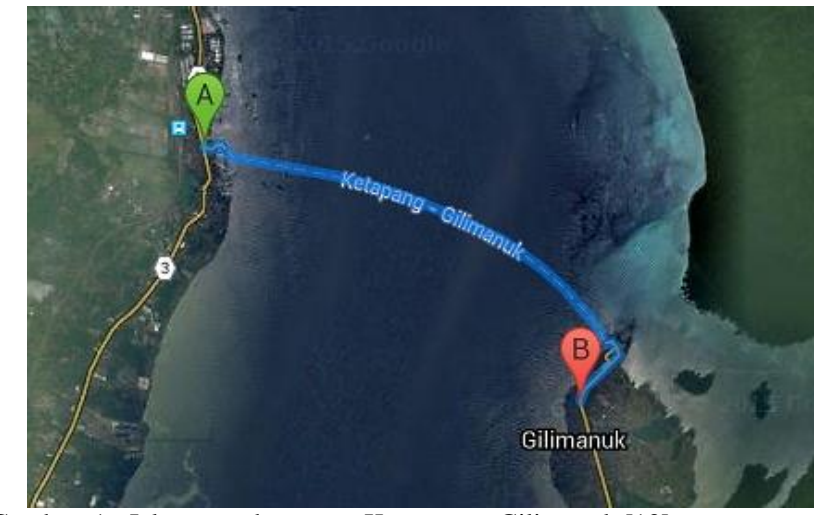

Gambar. 1. Jalur penyeberangan Ketapang - Gilimanuk [13] 
Menurut Dinas Perhubungan Darat (2015), pada jalur penyeberangan Ketapang - Gilimanuk ada sekitar 22 kapal tipe KMP dan 12 kapal tipe LCT (Landing Carft Tank).

\section{B. Landing Craft Tank (LCT) dan Kapal Motor Penyeberangan (KMP)}

Landing Craft Tank (LCT) merupakan salah satu jenis kapal yang pada awalnya dirancang untuk keperluan militer, mengangkut alat tempur pada masa perang dunia II. LCT tidak memerlukan pelabuhan yang besar untuk mendaratkan barang yang diangkutnya dan bisa melakukan bongkar muat dimana saja, misalnya langsung di pinggir pantai.

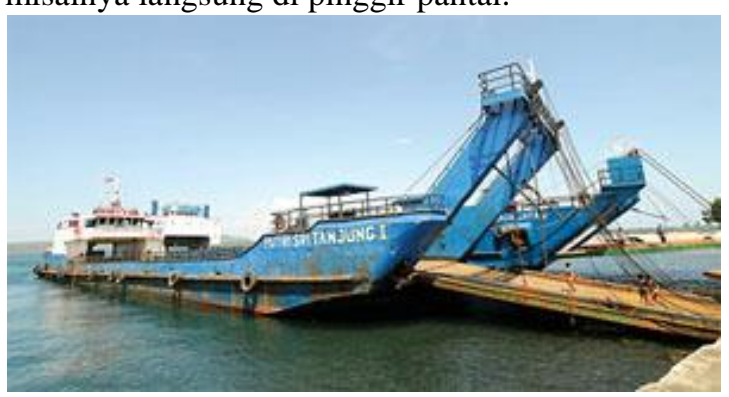

Gambar. 2. LCT Putri Sritanjung [11]

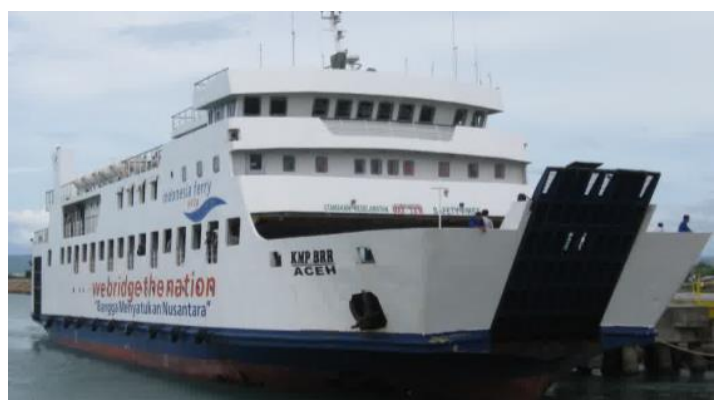

Gambar. 3. Kapal Motor Penyeberangan (KMP) [12]
Kapal Motor Penyeberangan (KMP) adalah tipe kapal yang digunakan sebagai angkutan penyeberangan antar pulau yang mengangkut kendaraan, barang, dan penumpang. Jangkauan penyeberangan kapal tipe KMP adalah dalam tujuan jarak dekat sehingga sering disebut sebagai transportasi pantai, sungai, dan danau [1].

\section{Konversi Kapal}

Dalam mengerjakan konversi, data yang dibutuhkan meliputi principal dimension, Lines Plan, General Arrangement, Construction Profile. Setelah didapatkan data-data di atas kemudian dilakukan redrawing dan pemodelan lambung kapal. Peraturan yang dipakai adalah BKI (Biro Klasifikasi Indonesia), peraturan internasional yang mengatur keselamatan jiwa di laut (SOLAS) dan Peraturan Garis Muat Indonesia untuk lambung timbul minimum [2].

\section{ANALISIS TEKNIS}

Sebelum mulai dilakukakan modifikasi harus didapatkan terlebih dahulu data kapal LCT Putri Sritanjung. LCT Putri Sritanjung merupakan kapal milik Pemerintah Kabupaten Banyuwangi yang dibangun pada tahun 2001 dan sejak tahun 2004 dikelola oleh PT. Pelayaran Banyuwangi Sejati (PBS) untuk melayani jalur penyeberangan Ketapang - Gilimanuk. Data kapal LCT Putri Sritanjung yang didapatkan dari PT. PBS berupa principal dimensions, Lines Plan, General Arrangement, dan Construction Profil. Setelah data tersebut didapatkan sebagai langkah awal bisa dilakukan pemodelan lambung LCT Putri Sritanjung. Untuk langkah selanjutnya dapat dilakukan modifikasi kapal dan analisis teknis lainnya.

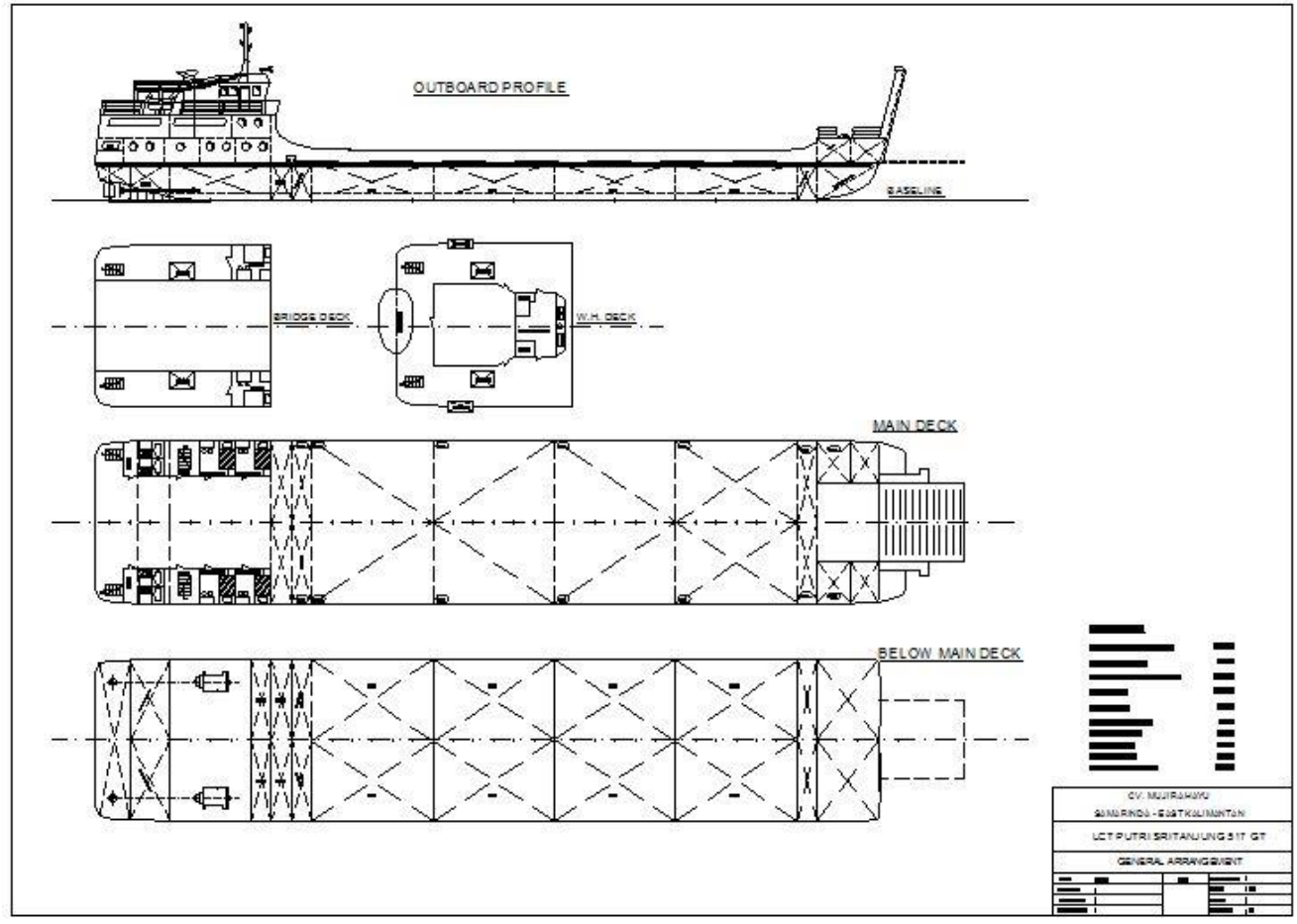

Gambar. 4. General Arrangement LCT Putri Sritanjung (sebelum konversi) 


\section{A. Pemodelan Lambung LCT Putri Sritanjung}

Tujuan pemodelan lambung LCT Putri Srianjung adalah untuk memperoleh perhitungan dan analisis yang lebih akurat, seperti pada perhitungan berat dan titik berat, kekuatan memanjang kapal, serta analisis stabilitas. Pemodelan lambung dilakukan menggunakan software maxsurf modeller.

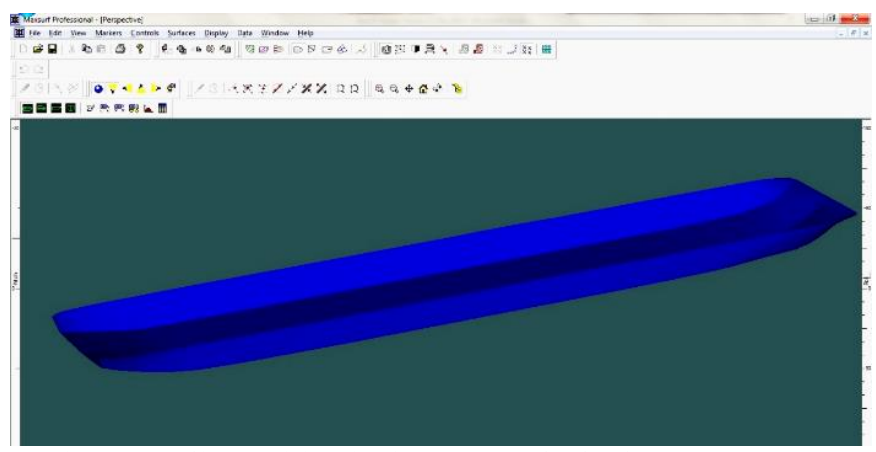

Gambar. 5. Hasil pemodelam lambung CT Putri Sritanjung

\section{B. Modifikasi LCT Putri Sritanjung Menjadi KMP Putri Sritanjung}

LCT Putri Sritanjung akan dimodifikasi menjadi KMP Putri Sritanjung, kapal penyeberangan tipe Ro-ro (roll on/ roll off). Modifikasi yang dilakukan adalah penambahan ruang akomodasi bagi penumpang dan penambahan ramp door sesuai dengan standar minimum angkutan penyeberangan menurut Peraturan Menteri Perhubungan Darat Nomor 80 [3] dan Nomor 39 [4].

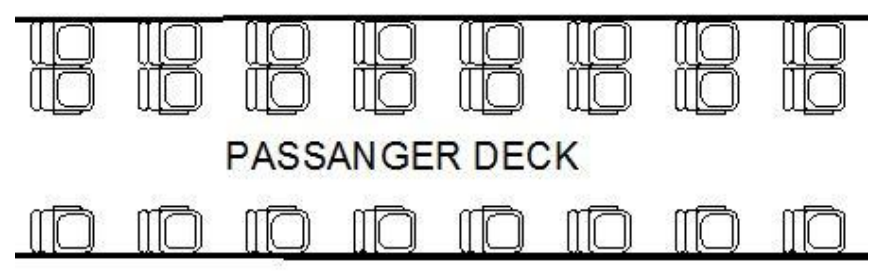

Gambar. 6. Posisi peletakan tempat duduk penumpang

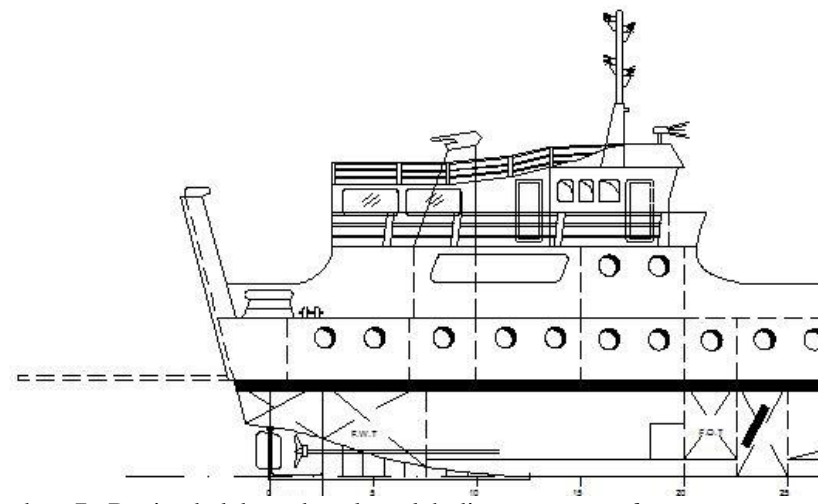

Gambar. 7. Bagian belakang kapal setelah dipasang ramp door

\section{Perhitungan Berat Kapal}

Setelah kapal dikonversi perlu dilakukan perhitungan untuk mendapatkan principal dimensions kapal setelah dilakukan konversi. Berat kapal total terdiri dari berat komponenkomponen DWT dan LWT. Dapat dilihat berat kapal total (displacement) yang terdiri dari komponen berat DWT dan LWT adalah 1088,319 ton (Tabel 1).
Tabel 1

Rekapitulasi Berat Kapal Total

\begin{tabular}{llc}
\hline \hline \multirow{2}{*}{ Komponen Berat } & \multicolumn{1}{c}{ Berat Bagian } & Berat (ton) \\
& & \\
\hline \multirow{2}{*}{ DWT } & Penumpang & 16,320 \\
& Kendaraan & 478,000 \\
& Crew and Consumbale & 54,205 \\
LWT & Baja & 330,533 \\
\multirow{2}{*}{ Displacment (ton) } & Peralatan dan Perlengkapan & 140,111 \\
& Mesin dan Perlengkapan & 90,352 \\
\hline \hline
\end{tabular}

\section{Perhitungan Titik Berat kapal}

Titik berat kapal dapat dihitung dari persebaran berat semua komponen berat disepanjang kapal. Untuk mendapatkan nilai persebaran berat lambung harus dilakukan persebaran berat DWT, berat mesin beserta perlengkapan, bangunan atas, dan peralatan serta perlengkapan terlebih dulu. Dari rekapitulasi persebaran berat kapal total dapat dihitung titik berat kapal total (LCG) dengan perhitungan sebagai berikut:

$L C G=\frac{\text { Total Momen }(\text { ton } . m)}{\text { Total Berat Kapal }(\text { ton })}$

Berdasarkan persamaan (1), didapatkan nilai LCG sebesar $0.513 \mathrm{~m}$ dari midship. Sedangkan titik berat kapal yang tercelup air (LCB) adalah $0,468 \mathrm{~m}$.

\section{E. Perhitungan Kekuatan Memanjang}

Perhitungan kekuatan memanjang kapal terdiri dari pengecekan modulus terhadap konstruksi memanjang kapal, pengecekan momen inersia kapal, dan pengecekan tegangan kapal baik saat kondisi air tenang maupun kondisi aor bergelombang (hogging dan sagging) [5].

1) Perhitungan Modulus

a. Modulus penampang terhadap alas $\left(\mathrm{W}_{\text {bott }}\right)$

$$
\mathrm{W}_{\text {bott }}=\frac{\mathrm{I}_{\mathrm{NA}}}{\mathrm{z} 1}=\frac{57,057,641.358}{131,608}=\mathbf{5 0 4 . 8 7 3 , 2 2 2} \mathrm{cm}^{3}
$$

b. Modulus penampang terhadap geladak $\left(\mathrm{W}_{\text {deck }}\right)$

$$
\mathrm{W}_{\text {deck }}=\frac{\mathrm{I}_{\mathrm{NA}}}{\mathrm{z} 2}=\frac{57,057,641.358}{143,392}=\mathbf{4 1 3 . 7 4 2 , 6 6 1} \mathrm{cm}^{3}
$$

c. Modulus minimum yang diijinkan menurut BKI Vol. II Sec 5.C.2 [5] adalah sebagai berikut:

$$
\begin{aligned}
\mathrm{W}_{\min } & =\mathrm{k} \cdot \mathrm{C}_{\mathrm{o}} \cdot \mathrm{L}^{2} \cdot \mathrm{B} \cdot(\mathrm{Cb}+0,7) \cdot 10^{-6} \mathrm{~m}^{3} \\
\mathrm{~W}_{\min } & =1 \times 6,360 \times 56,50^{2} \times 11,95 \times(0,738+0,7) \times 10 \\
& =\mathbf{0 , 3 4 8 8 8 3 8 0} \mathrm{m}^{3}
\end{aligned}
$$

2) Perhitungan Momen Inersia

Momen inersia minimum yang diijinkan adalah:

$\mathrm{I}_{\mathrm{y}}=3 \times 10^{-2} \times \mathrm{W} \mathrm{X} \mathrm{L/k} \mathrm{m}^{4}$

$\mathrm{I}_{\mathrm{y}}=3 \times 10^{2} \times 0,34888 \times 56,50 / 1$

$=0,591358039 \mathrm{~m}^{4}$

Momen inersia desain harus lebih atau sama dengan modulus minimum menurut BKI. Momen inersia desain $\left(\mathrm{I}_{\mathrm{NA}}\right)$ adalah $\mathbf{0 , 6 2 4} \mathrm{m}^{4}$, sehingga memenuhi ketentuan BKI.

3) Perhitungan Tegangan Kapal

Perhitungan tegangan kapal dilakukan pada dua kondisi, yaitu pada kondisi air tenang dan kondisi air bergelombang. 
Tabel 2.

Nilai constant ratio untuk berbagai kombinasi pasangan

\begin{tabular}{lccc}
\hline \hline & $\begin{array}{c}\sigma \text { Desain } \\
\left(\mathrm{Kn} / \mathrm{mm}^{2}\right)\end{array}$ & $\begin{array}{c}\sigma \mathrm{Ijin} \\
\left(\mathrm{Kn} / \mathrm{mm}^{2}\right)\end{array}$ & Koreksi \\
\hline $\begin{array}{l}\text { Kondisi Air Tenang } \\
\text { Wbottom }\end{array}$ & 68.828 & 1417.513 & $\begin{array}{c}\text { memenuhi } \\
\text { Wdeck }\end{array}$ \\
$\begin{array}{l}\text { Kondisi Hogging } \\
\text { Wbottom }\end{array}$ & 1105.404 & 1417.513 & memenuhi \\
Wdeck & 905.886 & 1417.513 & memenuhi \\
Kondisi Sagging & 1417.513 & memenuhi \\
Wbottom & 1248.957 & 1417.513 & memenuhi \\
Wdeck & 1023.518 & 1417.513 & memenuhi \\
\hline \hline
\end{tabular}

\section{F. Perhitungan Freeboard}

Pemeriksaan freeboard atau lambung timbul mengacu pada ketentuan International Convention on Load Lines (ICLL) 1966, IMO (International Maritime Organization) [6]. Pemeriksaan kondisi lambung timbul dilakukan pada kondisi kapal sebelum maupun sesudah dilakukan konversi.

$$
\text { Tabel } 3 \text {. }
$$

Hasil pemeriksaan freeboard

\begin{tabular}{lccc}
\hline \hline & \multicolumn{4}{c}{ Freeboard } & Freeboard & \\
Kondisi Kapal & Standar $(\mathrm{m})$ & $\begin{array}{c}\text { Sebenarnya } \\
(\mathrm{m})\end{array}$ & Koreksi \\
& & 0.25 & Tidak memenuhi \\
\hline Sebelum Konversi & 0.577 & 0.60 & memenuhi \\
Setelah Konversi & 0.526 & & \\
\hline \hline
\end{tabular}

\section{G. Perhitungan Tonnage}

Perhitungan tonnage atau tonase ada dua, yaitu gross tonnage (GT) dan net tonnage (NT). Ukuran tonnage kapal diperlukan pada saat proses pembayaran pajak dan sejenisnya. Besarnya tonase kapal dihitung berdasarkan International Convention on Tonnage Measurement of Ships 1969 [7].

1) Perhitungan Gross Tonnage (GT)

Gross Tonnage (GT) merupakan ukuran volume ruangan kapal yang tertutup secara keseluruhan, mulai dari ruangan kapal di bawah geladak cuaca $\left(\mathrm{V}_{\mathrm{U}}\right)$ sampai ruangan bangunan atas kapal $\left(\mathrm{V}_{\mathrm{H}}\right)$. Dan hasil perhitungan adalah sebagai berikut:

$$
\begin{aligned}
& \text { a. Total volume ruang tertutup } \\
& \mathrm{V}=\mathrm{V}_{\mathrm{U}}+\mathrm{V}_{\mathrm{H}} \\
&=2067,335 \mathrm{~m}^{3} \\
& \text { b. } \quad \mathrm{K}_{1}=0,2+0,02 \log \mathrm{V} \\
&=0,266308218 \\
& \mathrm{GT}=\mathrm{V} . \mathrm{K}_{1}=551
\end{aligned}
$$

2) Perhitungan Net Tonnage (NT)

Net Tonnage (NT) adalah volume ruang muat kapal $\left(\mathrm{V}_{\mathrm{C}}\right)$ dengan memperhitungkan jumlah orang dalam kapal. Dan hasil perhitungan adalah sebagai berikut:
a. Volume Ruang Muat
$\mathrm{V}_{\mathrm{C}}=1608 \mathrm{~m}^{3}$
b. $\mathrm{K} 2=0.2+0.02 \log \mathrm{V}_{\mathrm{C}}$
$=0.264$
c. $\mathrm{K} 3=1.25 \cdot \frac{G T+10000}{10000}$
$=1.265$
d. $\begin{aligned} \mathrm{NT} & =a+K_{3} \cdot\left(N_{1} \frac{N_{1}}{10}\right) \\ & =456.848\end{aligned}$
$=456.848$

\section{H. Pemeriksaan Kondisi Keseimbangan Kapal}

Kriteria kondisi pemuatan (loadcase) yang digunakan pada perhitungan ini mengacu pada Intact Stability (IS) Code Ch. III/3.5 [8] KMP Putri Sritanjung merupakan tipe kapal yang mengangkut kendaraan beserta muatannya dan penumpang. Sehingga kondisi pemuatannya sama dengan kapal penumpang barang. Kondisi pemuatan untuk kapal penumpang barang adalah sebagai berikut:

1) Loadcase 1: Kapal kosong

2) Loadcase 2: Kapal pada kondisi keberangkatan dengan muatan penuh, perbekalan dan bahan bakar penuh, jumlah penumpang penuh beserta barang bawaanya.

3) Loadcase 3: Kapal pada kondisi perjalanan dengan muatan penuh, jumlah penumpang penuh beserta barang bawannya, tetapi perbekalan dan bahan bakar sisa 50\%.

4) Loadcase 4: Kapal pada kondisi kedatangan dengan muatan penuh, jumlah penumpang penuh beserta barang bawannya, tetapi perbekalan dan bahan bakar sisa $10 \%$.

5) Loadcase 5: Kapal pada kondisi tanpa muatan, perbekalan dan bahan bakar penuh, jumlah penumpang penuh beserta barang bawannya.

6) Loadcase 6: Kapal pada kondisi tanpa muatan, jumlah penumpang penuh beserta barang bawannya, tetapi perbekalan dan bahan bakar sisa 50\%.

7) Loadcase 7: Kapal pada kondisi tanpa muatan, jumlah penumpang penuh beserta barang bawannya, tetapi perbekalan dan bahan bakar sisa $10 \%$.

\section{Pemeriksaan Kondisi Stabilitas}

Stabilitas merupakan salah satu kriteria yang harus dipenuhi pada proses desain kapal. Analisis stabilitas digunakan untuk mengetahui keseimbangan kapal secara melintang atau oleng pada beberapa kriteria kondisi pemuatan (loadcase). Kriteria stabilitas yang digunakan adalah kriteria stabilitas untuk kapal jenis umum dan kapal penumpang yang mengacu pada Intact Stability (IS) Code Reg. III/3.1.2 [9].

\section{Pemeriksaan Kondisi Trim}

Trim merupakan kondisi yang pasti terjadi, karena perubahan kondisi pemuatan secara otomatis pasti mengakibatkan perubahan letak titik berat kapal. Pemeriksaan trim ini mengacu pada SOLAS Reg. II/7 [10], dimana kondisi trim maksimum yang diperbolehkan adalah $0.5 \%$ Lwl. Pada software maxsurf stability pemeriksaan trim dapat dilihat melalui hasil analisis equilibrium. 
Tabel 4.

Hasil analisis stabilitas KMP Putri Sritanjung

\begin{tabular}{|c|c|c|c|c|c|c|c|c|c|}
\hline \multirow{2}{*}{ Criteria } & \multirow{2}{*}{ Value } & \multirow{2}{*}{ Unit } & \multicolumn{7}{|c|}{ Actual Condition } \\
\hline & & & 1 & 2 & 3 & 4 & 5 & 6 & 7 \\
\hline Area 0 to 30 shall be greater than $(>)$ & 3.151 & m.deg & 69.222 & 29.746 & 31.647 & 33.737 & 59.272 & 62.649 & 65.142 \\
\hline Area 0 to 40 shall be greater than (>) & 5.157 & m.deg & 89.495 & 42.046 & 44.835 & 48.123 & 63.566 & 75.577 & 86.920 \\
\hline Area of to 30 shall be greater than $(>)$ & 1.719 & m.deg & 69.222 & 27.046 & 27.789 & 28.510 & 59.272 & 62.649 & 65.142 \\
\hline Maximum GZ at 30 or greater shall be greater than (>) & 0.200 & $\mathrm{~m}$ & 3.425 & 1.267 & 1.358 & 1.473 & 2.858 & 3.043 & 3.180 \\
\hline Angle of maximum GZ shall be greater than (>) & 25 & $\operatorname{deg}$ & 35.9 & 26 & 26 & 26.5 & 31.5 & 33.9 & 33.9 \\
\hline Initial GMt shall be greater than $(>)$ & 0.15 & $\mathrm{~m}$ & 11.749 & 6.597 & 6.721 & 6.929 & 10.225 & 10.671 & 11.081 \\
\hline $\begin{array}{l}\text { Passenger crowding: angle of equilibrium } \\
\text { Angle of steady heel shall be less than }(<)\end{array}$ & 10 & $\operatorname{deg}$ & 0.30 & 0.30 & 0.30 & 0.30 & 0.30 & 0.30 & 0.30 \\
\hline $\begin{array}{l}\text { Turning: angle of equilibrium } \\
\text { Angle of steady heel shall be less than }(<)\end{array}$ & 10 & deg & 0.62 & 0.231 & 0.232 & 0.144 & 0.423 & 0.495 & 0.697 \\
\hline & & Status & PASS & PASS & PASS & PASS & PASS & PASS & PASS \\
\hline
\end{tabular}

Tabel 5.

Hasil pemeriksaan trim KMP Putri Sritanjung

\begin{tabular}{|c|c|c|c|c|c|c|c|}
\hline \multirow{2}{*}{ Kriteria } & \multicolumn{7}{|c|}{ Loadcase } \\
\hline & 1 & 2 & 3 & 4 & 5 & 6 & 7 \\
\hline Draft Amidsh m & 1.55 & 2.14 & 2.04 & 1.90 & 1.89 & 1.72 & 1.59 \\
\hline Displacement Tonne & 527.30 & 1088.00 & 1058.00 & 1032.00 & 610.40 & 580.00 & 554.00 \\
\hline Heel to Starboard degrees & 0.00 & 0.00 & 0.00 & 0.00 & 0.00 & 0.00 & 0.00 \\
\hline Draft at FP m & 1.45 & 2.15 & 2.08 & 2.00 & 1.77 & 1.59 & 1.46 \\
\hline Draft at AP m & 1.65 & 2.13 & 1.99 & 1.80 & 2.00 & 1.85 & 1.72 \\
\hline Draft at LCF $m$ & 1.27 & 2.14 & 2.09 & 2.06 & 1.41 & 1.36 & 1.31 \\
\hline Trim (+ve by stem) m & 0.19 & -0.02 & -0.10 & -0.20 & 0.23 & 0.26 & 0.26 \\
\hline WL Length m & 55.25 & 57.39 & 57.42 & 57.44 & 55.17 & 55.26 & 55.31 \\
\hline WL Beam m & 11.15 & 11.69 & 11.69 & 11.69 & 11.35 & 11.26 & 11.19 \\
\hline Block Coeff. & 0.55 & 0.74 & 0.71 & 0.69 & 0.53 & 0.54 & 0.55 \\
\hline LCB from Amidsh (+ve fwd) m & -4.26 & -0.47 & 0.10 & 0.61 & -5.86 & -5.11 & -4.40 \\
\hline Koreksi trim $(+/-\leq 5 \% \mathrm{Lwl})$ & 0.35 & -0.04 & -0.17 & -0.35 & 0.41 & 0.46 & 0.47 \\
\hline
\end{tabular}
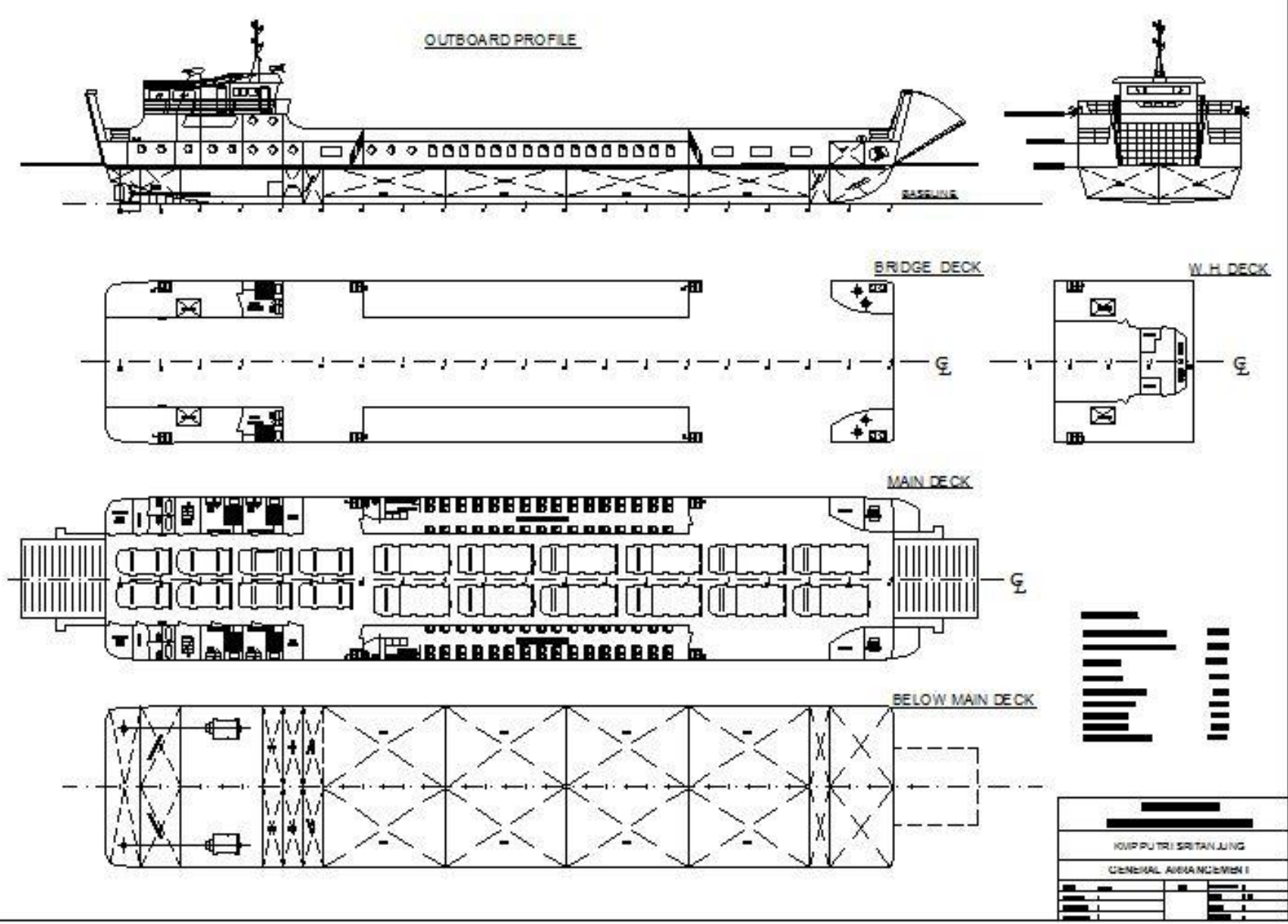

Gambar. 8. General Arrangement KMP Putri Sritanjung (setelah konversi) 


\section{ANALISIS EKONOMIS}

Berdasarnya pernyataan pihak Gapasdap (2015), biaya pembangunan kapal baru tipe KMP adalah 35 miliar rupiah jika dibangun di Indonesia. Dari hasil perhitungan biaya konversi ini nantinya bisa dibandingkan dengan biaya pembangunan kapal baru. Standar pekerjaan untuk melakukan konversi menggunakan standar repair PT. DPS Dan untuk harga peralatan dan perlengkapan tambahan seperti kursi penumpang, jendela, dan sebagainya, didapatkan dari berbagai sumber situs penjualan online. Berdasarkan rincian perhitungan biaya konversi didapatkan biaya total konversi LCT Putri Sritanjung menjadi KMP Putri Sritanjung adalah 2.000.640.524 rupiah.

\section{KESIMPULAN}

Pada Tugas Akhir ini dilakukan analisis secara teknis dan ekonomis pada konversi kapal LCT Putri Sritanjung menjadi KMP Putri Sritanjung. Berdasarkan hasil analisis yang telah dilakukan dapat disimpulkan bahwa konversi kapal ini memenuhi dari aspek teknis maupun ekonomis. Hasil analisis yang terdiri dari modifikasi kapal, perhitungan dan pemenuhan kriteria secara teknis dan ekonomis adalah sebagai berikut:

1) Penambahan ruang akomodasi penumpang terletak di main deck, tepatnya di depan poop deck atau diantara gading 30 dan 70 dengan lebar 2.625 meter pada setiap sisi kapal. Dan penambahan ramp door terletak di bagian belakang kapal (stern ramp door) dengan berat 25 ton. Sistem kerja ramp door secara mekanik menggunakan bantuan windlass

2) Pada perhitungan kekuatan memanjang kapal, nilai tegangan, modulus dan momen inersia konstruksi kapal memenuhi ketentuan BKI Vol. II Section 5. Tegangan konstruksi kapal maksimal sebesar 1.248,957 $\mathrm{kg} / \mathrm{cm}^{2}$ lebih kecil dari tegangan ijin BKI. Tinggi freeboard minimum menurut ICLL 1966 sebesar 0,557 meter dengan sarat maksimum 2.193 meter. Besarnya tonase kapal setelah dikonversi adalah 551 GT. Dan kondisi stabilitas kapal setelah dikonversi memenuhi kriteria Intact Stability (IS) Code Reg. III/3.1 berdasarkan hasil running pada Maxsurf Stability.

3) Pada perencanaan keselamatan kapal setelah dikonversi jumlah penumpang juga diperhitungkan. Berdasarkan ketentuan SOLAS 1974 terdapat penambahan 120 lifejacket, 2 open lifeboats, dan 6 inflatable liferaft.

4) Besarnya biaya total konversi LCT Putri Sritanjung menjadi KMP Putri Sritanjung yang dihitung secara preliminary engineer estimate adalah sebesar 2.000.640.524 rupiah, lebih sedikit dibandingkan biaya pembangunan kapal baru menurut pihak Gapasdap sebesar 35 miliar.

\section{UCAPAN TERIMA KASIH}

Penulis mengucapkan terima kasih kepada Allah SWT yang telah memberikan kesehatan, ilmu serta kelancaran bagi penulis, kedua orang tua penulis, Ibu Utami yang sudah tenang disisi-Nya dan Bapak Sarbini di rumah terimakasih atas kasih sayang, doa dan dukungannya selama ini yang tidak akan bisa terbalaskan, Ir. Hesty Anita Kurniawati, M.Sc selaku dosen pembimbing yang telah berkenan meluangkan waktu, membagikan ilmu dan memberikan arahan dalam pengerjaan Tugas Akhir ini. Teman-teman P52 - FORECASTLE yang tidak dapat penulis sebutkan satu per satu yang telah mendukung, menyemangati, menghibur, dan menemani semangat terus teman-teman. Terimakasih juga kepada Bapak Lutfi, Manajer PT. PBS yang telah berkenan memberikan data kapal LCT Putri Sritanjung.

\section{DAFTAR PUSTAKA}

[1] A. Wibowo, "Studi Perancangan Kapal Katamaran Multifungsi di Kawasan Sungai Banjir Kanal Barat Semarang," Jurnal Tugas Akhir Jurusan Tenik Perkapalan UNDIP, p. 51, 2012.

[2] Z. A. Fatahillah, "Analisis Teknis dan Ekonomis Konversi Landing Craft Tank (LCT) Menjadi Self Propelled Oil Borge (SPOB)," Surabaya: FTK-ITS.

[3] Peraturan Menteri Perhubungan No. 80 Standar Minimum Angkutan Penyeberangan, 2015.

[4] M. Perhubungan, Peraturan No. 39 Penyelenggaraan Angkutan Penyeberangan, 2015.

[5] B. K. I. (BKI), "Rule Construction of Hull for Sea Going Steel Ship," vol. II, pp. 5-3, 2009.

[6] L. Lines, International Convention on Load Lines, 1966, as Amended by the Protocol of 1988, 1966/1988.

[7] Tonnage - International Convention on Tonnage Measurement of Ships, 1969.

[8] "Intact Stability (IS) Code - Intact Stability for All Types of Ships Covered by IMO Instruments Resolution A 749 (18)," vol. III, no. 5, p. 18.

[9] "Intact Stability (IS) Code - Intact Stability for All Types of Ships Covered by IMO Instruments Resolution," A.749(18), vol. III, no. 1, p. 2.

[10] "International Convention for the Safety of Life at SeaSafety," vol. II, no. 7.

[11] Anonim, Fatwa News, [Online]. Available: http://www.fatwanews.com.

[12] Anonim, Trans News, [Online]. Available: http://www.beritatrans.com.

[13] Anonim, "Google Earth," Google, [Online]. Available: http://www.google-earth.com. 